\title{
MODEL PEMBELAJARAN SETS (SCIENCE, ENVIRONMENT, TECHNOLOGY, SOCIETY) BERBANTUAN VIRTUAL LAB BERPENGARUH TERHADAP KOMPETENSI PENGETAHUAN IPA
}

\author{
Ni Nyoman Ayu Sri Widiantini \\ Jurusan Pendidikan Guru Sekolah Dasar, Universitas Pendidikan Ganesha \\ E-mail: sriwidiantini@gmail.com \\ Jurusan Pendidikan Guru Sekolah Dasar, Universitas Pendidikan Ganesha \\ E-mail: putramd3112@yahoo.co.id \\ I Wayan Wiarta \\ Jurusan Pendidikan Guru Sekolah Dasar, Universitas Pendidikan Ganesha \\ E-mail:wayan.wiarta@yahoo.com
}

\begin{abstract}
Abstrak
Penelitian ini bertujuan untuk mengetahui pengaruh model pembelajaran SETS (Science, Environment, Technology, Society) berbantuan virtual laboratory (virtual lab) terhadap kompetensi pengetahuan IPA siswa kelas IV SD Gugus Mayor Metra Denpasar Utara Tahun Ajaran 2016/2017. Penelitian ini merupakan penelitian kuantitatif jenis eksperimen semu (quasi eksperiment) dengan desain “Nonequivalent control group design". Populasi dalam penelitian ini adalah seluruh siswa kelas IV SD Gugus Mayor Metra Denpasar Utara Tahun Ajaran 2016/2017 dengan jumlah populasi 391 siswa. Sampel dalam penelitian ini berjumlah 79 siswa yaitu 32 siswa kelas IV dari SD Negeri 18 Pemecutan yang menjadi kelompok eksperimen dan 47 siswa kelas IV dari SD Negeri 21 Pemecutan yang menjadi kelompok kontrol. Pemilihan sampel dalam penelitian ini menggunakan teknik random sampling. Data kompetensi pengetahuan IPA siswa dikumpulkan menggunakan metode tes yang kemudian dianalisis menggunakan uji-t. Berdasarkan hasil analisis uji-t dengan derajat kebebasan $(\mathrm{dk}=32+47-2=77)$ pada taraf signifikansi $5 \%$ diperoleh thitung $>\mathrm{t}_{\text {tabel }}$ ( $2,96>1,980$ ), sehingga $\mathrm{H}_{0}$ ditolak. Demikian pula nilai rata-rata kompetensi pengetahuan IPA kelompok eksperimen lebih dari

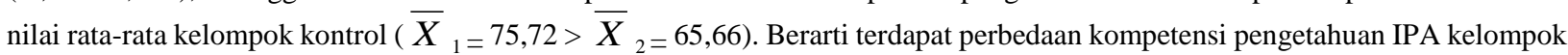
siswa yang dibelajarkan melalui model pembelajaran SETS berbantuan virtual lab dan kelompok siswa yang dibelajarkan tidak melalui model pembelajaran SETS berbantuan virtual lab. Sehingga dapat disimpulkan model pembelajaran SETS (science, environment, technology, society) berbantuan Virtual Laboratory (Virtual lab) berpengaruh terhadap kompetensi pengetahuan IPA siswa IV SD Gugus Mayor Metra Denpasar Utara Tahun Ajaran 2016/2017.
\end{abstract}

Kata kunci: model pembelajaran SETS, virtual lab, kompetensi pengetahuan IPA

\begin{abstract}
This research aims to know the influence of SETS learning model (science, environment, technology, society) of virtual laboratory (virtual lab) to competence of science knowledge elementary fourth grade students Gugus Mayor Metra North Denpasar district academic year 2016/2017. This research is an quasi experiment using Nonequivalent control group design. The research population was 391 elementary fourth grade students Gugus Mayor Metra North Denpasar district academic year 2016/2017. The sample of this research as much as 79 students, 32 fourth grade students of SD N 18 Pemecutan as experiment group and 47 fourth grade students of SD 21 Pemecutan as control group. Sample selection in this research using random sampling technique. The data competence of science knowledge of students collected using test method and then analyzed by t-test. Based on the result of $\mathrm{t}$-test analysis with degrees of freedom $(\mathrm{dk}=32+47-2=77)$ at $5 \%$ significance level obtained $t_{\text {hitung }}>\mathrm{t}_{\mathrm{tabel}}(2,96>1,980)$. As well as the average value competence of science knowledge of experimental group is more than the control group average score $\left(\bar{X}_{1=75,72>}\right.$ $\left.\bar{X}_{2}=65,66\right)$, then $\mathrm{H}_{0}$ is rejected. This means that there is difference competence of science knowledge groups of students that learned through SETS learning model of virtual lab and group of students that is not through SETS learning model of virtual lab. It can be concluded SETS learning model (science, environment, technology, society) of virtual laboratory (virtual lab) has effect on competence of science knowledge fourth elementary grade students Gugus Mayor Metra North Denpasar district academic year $2016 / 2017$.
\end{abstract}

Keywords : SETS learning model, virtual lab, competence of science knowledge 


\section{Pendahuluan}

Peranan kurikulum dalam pendidikan formal sangatlah strategis dan menentukan pencapaian tujuan pendidikan nasional. Kurikulum memiliki kedudukan dan posisi yang sangat sentral dalam keseluruhan proses pendidikan, bahkan kurikulum merupakan syarat mutlak dan bagian yang tidak terpisahkan dari pendidikan (Hermawan, 2010). Pemerintah secara berkesinambungan mewujudkan tujuan pendidikan dengan menyempurnakan kurikulum tingkat satuan pendidikan (KTSP) menjadi kurikulum 2013 (Suarjana dan Japa, 2015). Menurut permendikbud Nomor 103 Tahun 2014 lampiran 4 menetapkan proses pembelajaran pada Kurikulum 2013 untuk semua jenjang dilaksanakan dengan menggunakan pendekatan ilmiah (saintifik).

Daryanto (2014:51) menyatakan "pembelajaran dalam pendekatan saintifik dirancang agar siswa secara aktif mengontruksi konsep, hukum atau prinsip melalui tahapan-tahapan mengamati (untuk mengidentifikasi atau menemukan masalah), merumuskan masalah, mengajukan atau merumususkan hipotesis, mengumpulkan data dengan berbagai teknik, menganalisis data, menarik kesimpulan dan mengkomunikasikan konsep dengan bantuan guru akan tetapi guru tidak mendominasi pembelajaran"

Salah satu muatan pelajaran yang terdapat dalam kurikulum 2013 adalah muatan pelajaran IPA. Samatowa (2011:3) menyatakan "ilmu Pengetahuan Alam (IPA) merupakan ilmu yang mempelajari peristiwa-peristiwa yang terjadi di alam serta gejala-gejala alam yang disusun secara sistematis yang berdasarkan hasil percobaan dan pengamatan". Pembelajaran IPA merupakan pembelajaran yang berdasakan pada prinsip-prinsip, proses yang dapat menumbuhkan sikap ilmiah siswa terhadap konsep-konsep IPA, oleh karena itu pembelajaran IPA di SD dilakukan dengan penyelidikan sederhana dan bukan hafalan terhadap kumpulan konsep IPA. Berdasarkan kegiatan-kegiatan tersebut pembelajaran IPA akan memungkinkan siswa mendapatkan pengalaman langsung yang bermakna (Susanto, 2014). Pembelajaran IPA untuk sebagian besar siswa merupakan pembelajaran yang sulit, sehingga secara tidak langsung dapat mempengaruhi keberhasilan siswa dalam pembelajaran (Wisudawati dan Eka, 2014).

Hal ini terbukti dari hasil observasi dan wawancara yang dilaksanakan pada tanggal 19 Januari 2017 dengan wali kelas IV di semua SD Gugus Mayor Metra Denpasar Utara. Berdasarkan nilai UAS semester ganjil siswa kelas IV di semua Gugus Mayor Metra pada muatan ajaran IPA, dari seluruh siswa yang berjumlah 391, 40 siswa mendapat nilai A, 22 siswa mendapat nilai $\mathrm{A}^{-}, 118$ siswa mendapat nilai $\mathrm{B}^{+}, 115$ siswa mendapat nilai $\mathrm{B}, 19$ siswa mendapat nilai $\mathrm{B}^{-}$, dan 77 siswa mendapat nila C. Sedangkan kriteria ketuntasan minimal yang diharapkan oleh kurikulum 2013 adalah 66,5 $\left(B^{-}\right)$. Jadi siswa yang memperoleh nilai dibawah kriteria ketuntasan minimal yang diharapkan oleh kurikulum 2013 adalah 77 siswa $(19,7 \%)$ dan $314(80,3 \%)$ siswa yang tergolong tuntas. Berdasarkan hal tersebut terdapat kesenjangan antara harapan kurikulum 2013 yang menetapkan kreteria ketuntansaan minimal $\mathrm{B}^{-}$untuk muatan pembelajaran IPA dengan kenyataan masih terdapat siswa yang mendapat nilai di bawah B:

Dari permasalahan tersebut dipandang perlu adanya inovasi dalam pembelajaran yakni pembelajaran yang mengutamakan kompetensi pengetahuan, berpusat pada siswa, memberikan pengalaman belajar langsung yang bermakna, dan relevan dengan kehidupan nyata. Satu diantara inovasi yang dapat digunakan untuk meningkatkan kompetensi pengetahuan IPA adalah dengan menerapkan model pembelajaran SETS (Science, Environment, Technology, Society) berbantuan Virtual Laboratory (Virtual lab).

"Kompetensi merupakan suatu yang sangat komplek, yang didalamnya mengandung banyak aspek atau ranah" (Kosaih, 2014:14). "IPA merupakan salah satu mata pejaran pokok dalam kurikulum pendidikan di Indonesia, termasuk dalam jenjang SD" (Susanto, 2014:165). Kosasih (2014:21) menyatakan "taksonomi tujuan pengajaran dalam kompetensi pengetahuan menurut Bloom terdiri atas enam tingkatan kemampuan berfikir yakni pengatahuan, pemahaman, penerapan, analisis, sintesis, dan evaluasi". Keenam kategori tersebut kemudian disempurnakan oleh Lorin Anderson Krathwohl dengan istilah serta urutan sebagai berikut. (1) Mengingat (Remembering), (2) Memahami (Understanding), (3) Menerapkan (Applying), (4) Menganalisis (Analizing), (5) Mengevaluasi (Evaluating), (6) Mencipta (Creating).

Penyempurnaan keenam tingkatan kemampuan berfikir oleh Lorin Anderson Krathwohl ini sering digunakan dalam merumuskan tujuan pembelajaran yang sering dikenal dengan istilah C-1 sampai dengan C-6. Pengukuran kompetensi pengetahuan IPA keenam tingkatan kemampuan berfikir berkaitan dengan dimensi pengatahuan. Menurut Nurgiyantoro (2016:85) "dimensi pengetahuan merupakan dimensi yang tersendiri di samping proses kognitif". Dimensi pengetahuan dalam taksonomi Anderson dibedakan ke dalam empat kategori yaitu pengatahuan faktual, pengetahuan konseptual, pengetahuan prosedural, dan pengetahuan metakognitif.

Berdasarkan pendapat serta pemaparan berbagai teori dapat disimpulkan bahwa kompetensi pengetahuan IPA merefleksikan konsep-konsep keilmuan yang harus dikuasai oleh siswa dalam pembelajaran dengan melalui tingkatan kemampuan berfikir yang meliputi mengingat, memahami, menerapkan, menganalisis, mengevaluasi dan mencipta serta dimensi pengetahuan pengatahuan faktual, pengetahuan konseptual, pengetahuan prosedural, dan pengetahuan metakognitif.

Model pembelajaran SETS merupakan suatu model pembelajaran yang memusatkan permasalahan dari dunia nyata yang memiliki komponen sains dan teknologi dari perspektif siswa, di dalamnya terdapat konsep-konsep dan proses, selanjutnya siswa diajak untuk menginvestigasi, menganalisis, dan menerapkan konsep, dan proses itu pada situasi yang nyata (Fatchan dkk, 2014). Pembelajaran dengan model pembelajaran SETS sangat cocok diterapkan 
untuk pembelajaran IPA. Model pembelajaran SETS membuat pembelajaran IPA lebih menarik, menyenangkan, dan bermakna karena siswa diberi kesempatan untuk memperoleh pengetahuan tidak hanya dari buku melainkan dengan memanfaatkan teknologi, lingkungan dan masyarakat. Hal ini akan membuat pembelajaran lebih menarik dan menyenangkan, sehingga pengetahuan yang diterima siswa tidak cepat dilupakan.

Menurut Wisudawati dan Eka (2014) siswa sekarang ini sangat menyukai hal-hal yang berhubungan dengan teknologi komputer, namun hal ini membuat siswa malas untuk belajar. Langkah yang dapat diambil guru untuk mengatasi masalah tersebut dengan memanfaatkan teknologi dalam proses pembelajaan. Satu diantara banyak teknologi yang dapat digunakan adalah virtual laboratory. Virtual laboratory atau lebih dikenal dengan nama virtual $l a b$ merupakan suatu media berbasis komputer yang berisi simulasi kegiatan di laboratorium. Virtual lab dibuat untuk menggambarkan reaksi-reaksi yang mungkin tidak dapat terlihat pada keadaan nyata. Virtual lab didefenisikan sebagai suatu objek multimedia intraktif. Objek multimedia interaktif terdiri dari bermacam format heterogen termasuk teks, hiperteks, suara, gambar, animasi, video, dan grafik (Hermansyah dkk, 2015).

Model pembelajaran SETS dipadukan dengan virtual lab akan membuat proses pembelajaran lebih menyenangkan. Hal itu karena model pebelajaran SETS berbantuan virtual lab membantu siswa memperoleh pengetahuan tidak hanya dari buku melainkan juga dapat memanfaatkan lingkungan, masyarakat dan teknologi yang berisikan simulasi-simulasi kegiatan di laboratorium dalam bentuk teks, hiperteks, suara, gambar, animasi, video, dan grafik.

Menurut Wisudawati dan Eka (2014:73) menyatakan "model pembelajaran SETS merupakan suatu model pembelajaran yang menghubungkan sains dengan unsur lain, yaitu teknologi, lingkungan, maupun masyarakat. Pengembangan dan penelitian terhadap efektivitas model pembelajaran SETS telah banyak dilakukan. Pengembangan konsep Green Chemistry dalam proses pembelajaran IPA, penelitian tentang sikap peduli lingkungan siswa, serta pengemasan SETS dalam pembelajaran edutainment merupakan contoh penelitian dan pengembangan model pembelajaran SETS. Penelitian dan pengembangan tersebut beruaya untuk meningkatkan kualitas pembelajaran IPA dan kualitas hidup manusia yang selalu memerhatikan lingkungan kehiduan dan sistem kehidupan”.

Penggunaan model pembelajaran SETS dalam pembelajaran dapat dipadukan dengan virtual lab. Virtual lab dibuat untuk menggambarkan reaksi-reaksi yang mungkin tidak dapat terlihat pada keadaan nyata. Virtual lab didefenisikan sebagai suatu objek multimedia interaktif. Objek multimedia interaktif terdiri dari bermacam format heterogen termasuk teks, hiperteks, suara, gambar, animasi, video, dan grafik (Hermansyah dkk, 2015). Keberadaan virtual lab diharapkan dapat menjadi solusi bagi kendala-kendala yang dihadapi untuk melakukan praktikum maupun kegiatan yang berkaitan dengan pembelajaran IPA yang tidak bisa ditemukan serta dilakukan di sekolah.

Berdasarkan beberapa teori tersebut dapat disimpulkan bahwa model pembelajaran SETS berbantuan virtual $l a b$ adalah model pembelajaran yang membantu siswa memperoleh pengetahuan tidak hanya dari buku melainkan juga dapat memanfaatkan, lingkungann, masayarakat dan teknologi yang berisikan simulasi-simulasi kegiatan di laboratorium yang berbentuk perangkat lunak (software) komputer berbasis multimedia interaktif dalam bentuk teks, hiperteks, suara, gambar, animasi, video, maupun grafik yang dioperasikan dengan komputer dan dapat mensimulasikan kegiatan di laboratorium. Model Pembelajaran SETS terdiri dari empat tahap yaitu tahap invitation, tahap exsploration, tahap penjelasan (Explanation) dan solusi dan yang terakhir tahap tindak lanjut (Sutarno, 2008).

Model pemebelajaran SETS memiliki kelebihan menurut Fatchan (2014) sebagai berikut. (a) Dapat meningkatkan keterampilan inkuiri, keterampilan pemecahan, dan keterampilan proses, menekankan cara belajar yang baik yang mencakup ranah kognitif, afektif dan psikomotorik, menekankan sains dalam keterpaduan dan antara bidang studi, (b) Jika ditinjau dari segi pembelajaran, menekankan keberhasilan siswa, bisa digabungkan dengan berbagai strategi pembelajaran, menyadarkan guru bahwa kadang-kadang dirinya tidak selalu berfungsi sebagai sumber informasi, (c) Jika ditinjau dari segi evaluasi ada hubungan antara tujuan, proses dan hasil belajar, perbedaan antara kecakapan, kematangan serta latar belakang siswa serta fungsi program juga dievaluasi.

Menurut Wisudawati dan Eka (2015) menyatakan kelebihan virtual lab adalah sebagai berikut. (a) Ekonomis, tidak membutuhkan bangunan laboratorium, alat-alat dan bahan-bahan seperti pada laboratorium konvensional, (b) Mengurangi hambatan geografis, jika terdapat siswa atau mahasiswa yang berlokasi jauh dari pusat pembelajaran, (c) Mengurangi keterbatasan waktu, jika tidak ada cukup waktu untuk mengajari seluruh siswa di dalam lab hinga mereka paham, (d) Meningkatkan kualitas eksperimen, karena memungkinkan untuk diulang untuk memperjelas keraguan dalam pengukuran di lalaboratorium, (e) Meningkatkan efektivitas pembelajaran, karena siswa atau mahasiswa akan semakin lama menghabiskan waktunya dalam laboratorium virtual tersebut berulang-ulang, (f) Meningkatkan keamanan dan keselamatan, karena tidak berinteraksi dengan alat dan bahan yang nyata.

Jadi dapat simpulkan kelebihan model pembelajaran SETS berbantuan vitual lab adalah sebagai berikut. (a) Melatih siswa untuk berpikir kritis, (b) Siswa mendapat pengalaman belajar yang bermakna, (c) Meningkatkan minat siswa karena mereka dapat mensimulasikan kegiatan-kegiatan yang berkaitan dengan IPA menggunakan teknologi maupun lingkungan, (d) Ekonomis, karena tidak membutuhkan ruangan laboratium khusus, dan peralatan yang menunjang kegiatan laboratium, (e) Mengurangi hambatan geografis, jika terdapat sekolah yang berlokasi jauh dari sumber pembelajaran. Sehingga pembelajaran dengan model pembelajaran SETS berbantuan virtual lab sangat tepat 
diterapkan dalam pembelajaran terutama dalam pembalajaran IPA kerena memiliki banyak kelebihan yang dapat membuat pembelajaran menjadi lebih menyenangkan tidak membosankan, dan bermakna.

\section{Metode Penelitian}

Penelitian ini dilaksanakan di Gugus Mayor Metra Kecamatan Denpasar Utara. Waktu pelaksanaan penelitian adalah pada semester genap tahun ajaran 2016/2017. Penelitian yang akan dilakukan adalah penelitian kuantitatif dengan desain eksperimental yaitu Eksperimen Semu (quasi eksperiment). Populasi dari penelitian ini adalah seluruh siswa kelas IV SD Gugus Mayor Metra Denpasar Utara tahun ajaran 2016/2017, yang terdiri dari 10 kelas dalam 4 SD. Jumlah populasi dari penelitian ini adalah 391 orang siswa. Sampel dalam penelitian ini diperoleh dengan teknik randon sampling .

Berdasarkan hasil randon sampling diperoleh 2 kelas sebagai sampel yaitu SD N 18 Pemecutan dan SD N 21Pemecutan. Kemudian sampel diberikan pretest untuk mengetahui sampel setara secara akademik. Pemberian pretest biasanya digunakan untuk menyetarakatan kelompok (Dantes, 2012). Berdasarkan hasil pretest SD N 18 Pemecutan dan SD N 21 Pemecutan setara dari segi akademik, jika sudah setara secara akademik kedua kelas ini di randomisasi untuk menentukan kelompok eksperimen dan kelompok kontrol. Berdasarkan hasil randomisasi SD N 18 Pemecutan sebagai kelompok eksperimen dan SD N 21 Pemecutan sebagai kelas konrol. Metode pengumulan data dalam penelitian ini dengan menggunakan metode tes untuk mengukur kompetensi pengetahuan IPA siswa.

Tes yang digunakan adalah tes pilihan ganda biasa yang berjumlah 40 soal. Bersadarkan hasil uji instrument terdapat 28 soal yang valid, dari 28 soal yang dinyatakan valid terdapat 7 soal mudah, 12 soal sedang dan 9 soal yang sukar. Tes pilihan ganda pada penelitian ini tergolong reliabel dengan kreterian derajat reliabilitas sangat tinggi. Penelitian menggunakan 2 variabel yaitu variabel bebas dan varibel terikat. Variabel bebas dalam penelitian ini adalah model pembelajaran SETS berbatuan virtual lab dan variabel terikat dalam penelitian ini adalah kompetensi pengetahuan IPA.

Teknik analisis data yang digunakan adalah teknik analisis statistik deskriptif dan statistik inferensial. Teknik analisis deskritif digunakan untuk menjawab ruusan masalah satu dan dua berupa penghituangan mean, standar deviasi, dan varian. Hasil analisis deskriptif kemudian disajikan dalam bentuk histrogram dan dilihat pencapaiannya dengan mengkatagorikan pada PAP skala lima. Teknik statistik inferensial digunakan untuk menjawab rumusan masalah ketiga didahului dengan uji prasyarat berupa uji normalitas dan uji homogenitas. Pada uji inferensial, untuk menguji hipotesis digunakan uji beda mean (uji-t) dengan rumus volled varian.

\section{Hasil dan Pembahasan}

Deskripsi data kompetensi pengetahuan IPA memaparkan nilai rata-rata, standar deviasi, varians, nilai minimum dan nilai maksimum. Pengolahan data dikerjakan dengan bantuan program pengolah angka Microsoft Office Excel 2007. Hasil deskripsi data penguasaan kompetensi pengetahuan IPA siswa kelas IV SD Gugus Mayor Metra tahun pelajaran 2016/2017 dapat dilihat pada Tabel 1. Deskripsi Data Kompetensi Pengetahuan IPA berikut ini.

Tabel 1. Deskripsi Data Kompetensi Pengetahuan IPA

\begin{tabular}{lcc}
\hline \multicolumn{1}{c}{ Hasil Analisis } & Kelompok Eksperimen & Kelompok Kontrol \\
\hline Mean & 75,72 & 65,66 \\
Standar Deviasi & 206,34 & 239,40 \\
Varian & 14,36 & 15,47 \\
Nilai Minimum & 46 & 36 \\
Nilai Makimum & 100 & 100 \\
\hline
\end{tabular}

Frekuensi nilai posttest kompetensi pengetahuan IPA kelompok eksperimen dapat dilihat pada Gambar 1. Histogram Distribusi Frekuensi Kompetensi Pengetahuan IPA Kelompok Eksperimen berikut ini.Garis-garis tabel diutamakan garis horizontal saja sedangkan garis vertikal dihilangkan. 


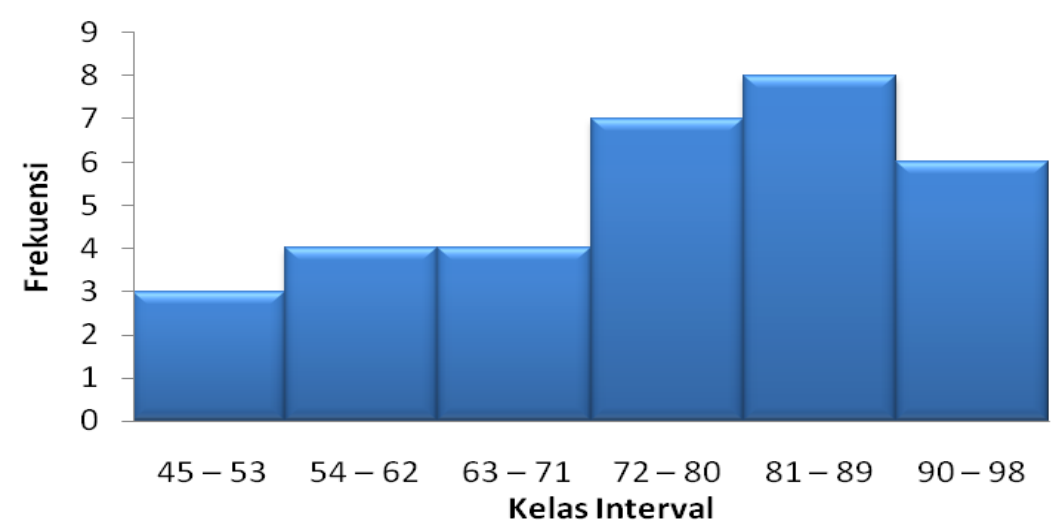

Gambar 1. Histogram Distribusi Frekuensi Kompetensi Pengetahuan IPA Kelompok Eksperimen

Sedangkan penjelasan mengenai frekuensi nilai posttest kompetensi pengetahuan IPA kelompok kontrol dapat dilihat pada Gambar 2. Histogram Distribusi Frekuensi Kompetensi Pengetahuan IPA Kelompok kontrol berikut ini.

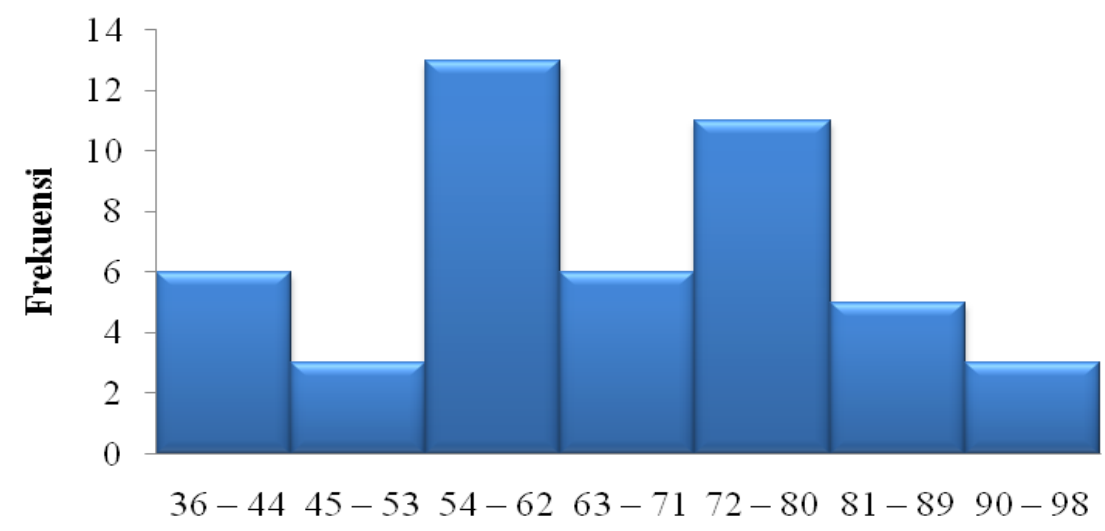

Kelas Interval

Gambar 2. Histogram Distribusi Frekuensi Kompetensi Pengetahuan IPA Kelompok Kontrol

Sebelum dilakukan pengujian hipotesis terlebih dahulu dilakukan uji prasyarat yang meliputi uji normalitas sebaran data dan uji homogenitas. Uji normalitas sebaran data dilakukan untuk mengetahui sebaran data hasil penelitian berdistribusi normal atau tidak. Uji normalitas data kompetensi pengetahuan IPA siswa mempergunakan rumus analisis Chi-Kuadrat $\left(\chi^{2}\right)$ pada taraf signifikansi 5\% dan derajat kebebasan $(\mathrm{dk})=\mathrm{k}-1$.

Dari hasil uji normalitas sebaran data kelompok eksperimen diperoleh $x^{2}{ }_{h}=4,48$. Harga tersebut kemudian dibandingkan dengan harga $x^{2}$ tabel dengan $\mathrm{dk}=5$ dan taraf signifikansi 5\% sehingga diperoleh harga $x_{\text {tabel }}^{2}=11,07$, karena $x^{2}$ hitung $<x_{\text {tabel }}^{2}(4,48<11,07)$ maka $\mathrm{H}_{0}$ diterima atau $\mathrm{H}_{\mathrm{a}}$ ditolak. Ini berarti sebaran data kompetensi pengetahuan IPA siswa kelompok eksperimen berdistribusi normal. Berdasarkan hasil uji normalitas sebaran data kelompok kontrol diperoleh $x^{2}{ }_{h}=2,10$. Harga tersebut kemudian dibandingkan dengan harga $x^{2}$ tabel dengan $\mathrm{dk}=5 \mathrm{dan}$ taraf signifikansi 5\% sehingga diperoleh harga $x_{\text {tabel }}^{2}=11,07$, karena $x^{2}{ }_{\text {hitung }}<x^{2}$ tabel $(2,10<11,07)$ maka $\mathrm{H}_{0}$ diterima atau $\mathrm{H}_{\mathrm{a}}$ ditolak. Ini berarti sebaran data kompetensi pengetahuan IPA kelompok kontrol normal.

Uji homogenitas varians ini dilakukan berdasarkan data kompetensi pengetahuan IPA yang meliputi data kelompok eksperimen yang dibelajarkan melalui model pembelajaran SETS berbantuan virtual lab dan kelompok kontrol yang dibelajarkan tidak melalui model pembelajaran SETS berbantuan virtual lab. Uji homogenitas varians dalam penelitian ini menggunakan uji $\mathrm{F}$.

Berdasarkan hasil pengujian homogenitas varians data kelompok eksperimen dan kelompok kontrol diperoleh hasil yang disajikan pada Tabel 2. Hasil Uji Homogenitas Varians Data Posttest. 
Tabel 2. Hasil Uji Homogenitas Varians Data Posttest

\begin{tabular}{lcccc}
\hline \multicolumn{1}{c}{ Sampel } & Varians & $\mathrm{F}_{\text {hitung }}$ & $\mathrm{F}_{\text {tabel }}$ & Kesimpulan \\
\hline Kelompok Eksperimen & 206,72 & & & \\
Kelompok Kontrol & 239,40 & 1,16 & 1,65 & Homogen \\
\hline
\end{tabular}

Berdasarkan hasil uji homogenitas varians menunjukkan bahwa $\left(F_{\text {hitung }}=1,16<F_{\text {tabel }}=1,65\right)$ Ini berarti bahwa varians antara kelompok eksperimen dan kelompok kontrol homogen.

Berdasarkan hasil uji normalitas dan homogenitas dapat diketahui bahwa data yang diperoleh dari kelompok eksperimen dan kelompok kontrol berdistribusi normal dan memiliki varians yang homogen. Karena data yang diperoleh telah memenuhi semua prasyarat, uji hipotesis dilakukan dengan menggunakan analisis uji-t. Adapun kriteria pengujiannya adalah apabila $t_{\text {hitung }} \leq t_{\text {tabel }}$, maka $\mathrm{H}_{\mathrm{o}}$ diterima. Sebaliknya apabila $t_{\text {hitung }}>t_{\text {tabel }}, \mathrm{maka}_{\mathrm{o}} \mathrm{H}_{\mathrm{o}}$ ditolak. Dengan $\mathrm{db}=\mathrm{n}_{1}+\mathrm{n}_{2}-2$ dan taraf signifikansi $5 \%(\alpha=0,05)$.

Berdasarkan hasil analisis uji-t dari data penguasaan kompetensi pengetahuan IPA siswa diperoleh hasil sesuai dengan Tabel 3. Hasil Analisis Uji-t Data Posttest sebagai berikut berikut.

Tabel 3. Hasil Analisis Uji-t Data Posttest

\begin{tabular}{llcccccl}
\hline No & \multicolumn{1}{c}{ Sampel } & $\begin{array}{c}\text { Rata- } \\
\text { rata }\end{array}$ & Varians & $\mathrm{N}$ & $\mathrm{t}_{\text {hitung }}$ & $\mathrm{t}_{\text {tabel }}$ & Kesimpulan \\
\hline 1 & Kelompok Eksperimen & 75,72 & 206,34 & 32 & \multirow{2}{*}{2,96} & 1,980 & $\mathrm{H}_{0}$ ditolak \\
2 & Kelompok Kontrol & 65,66 & 239,40 & 47 & 2,66 & \\
\hline
\end{tabular}

Berdasarkan hasil analisis data diperoleh $t_{\text {hitung }}$ sebesar 2,96. Harga tersebut kemudian dibandingkan dengan harga $t_{\text {tabel. }}$. Harga $t_{\text {tabel }}$ diperoleh dari tabel nilai-nilai dalam distribusi $t$ dengan derajat kebebasan $(\mathrm{dk}=32+47-2=$ 77), pada taraf signifikansi 5\%. Berdasarkan tabel nilai-nilai dalam distribusi t diperoleh harga $t_{\text {tabel }}$ sebesar 1,980 . Karena $t_{\text {hitung }}>t_{\text {tabel }}(2,96>1,980)$ maka $H_{o}$ ditolak. Hal ini berarti terdapat perbedaan yang signifikan kompetensi pengetahuan IPA kelompok siswa yang dibelajarkan melalui model pembelajaran SETS (Science, Environment, Technology, Society) berbantuan Virtual Laboratory (Virtual lab) dan kelompok siswa yang dibelajarkan tidak melalui model pembelajaran SETS (Science, Environment, Technology, Society) berbantuan Virtual Laboratory (Virtual lab) pada siswa kelas IV SD Gugus Mayor Metra Denpasar Utara tahun ajaran 2016/2017. Jadi dapat disimpulkan model pembelajaran SETS (Science, Environment, Technology, Society) berbantuan Virtual Laboratory (Virtual lab) berpengaruh terhadap kompetensi IPA siswa kelas IV SD Gugus Mayor Metra Denpasar Utara tahun ajaran 2016/2017.

Perbedaan yang signifikan kompetensi pengetahuan IPA antara kelompok kontrol dan eksperimen terjadi akibat perlakukan yang berbeda antara kelompok kontrol dan kelompok eksperimen. Pada kelompok eksperimen siswa dibelajarakan dengan model pembelajaran SETS berbantuan virtual lab. Pembelajaran dengan menggunakan model pembelajaran SETS berbantuan virtual lab memiiki beberapa kelebihan. Merurut Fatchan (2014) kelebihan model pembelajaran SETS yaitu (1) Dapat meningkatkan keterampilan inkuiri, keterampilan pemecahan, dan keterampilan proses, menekankan cara belajar yang baik yang mencakup ranah kognitif, afektif dan psikomotorik, menekankan sains dalam keterpaduan dan antara bidang studi. (2) Jika ditinjau dari segi pembelajaran, menekankan keberhasilan siswa, bisa digabungkan dengan berbagai strategi pembelajaran, menyadarkan guru bahwa kadangkadang dirinya tidak selalu berfungsi sebagai sumber informasi. (3) Jika ditinjau dari segi evaluasi ada hubungan antara tujuan, proses dan hasil belajar, perbedaan antara kecakapan, kematangan serta latar belakang siswa serta fungsi program juga dievaluasi.

Kelas eksperimen dalam pembelajaran selama penelitian memanfaatkan lingkungan sekolah untuk memperoleh informasi mengenai materi yang dipelajari yaitu materi IPA gaya dan gerak, siswa memanfaatkan lingkungan sekitar sekolah untuk mengamati benda-benda yang ada di sekitar sekolah yang dapat menghasilkan gerak setelah diberi gaya, selain itu juga mengamati perubahan yang terjadi pada benda setelah diberi gaya dan bergerak. Kemudian siswa memanfaatkan masyarakat untuk berinteraksi dalam menemuakan informasi, jadi siswa tidak hanya diajarkan untuk memanfaatkan lingkungan untuk memperoleh informasi tetapi juga memanfaatkan masyarakat untuk memperoleh informasi. Selain lingkungan dan masyarakat pembelajaran dengan model pembelajaran SETS berbantuan virtual lab juga memanfaatkan teknologi, dalam penelitian teknologi yang digunakan adalah dengan virtual lab. Virtual lab yang digunakan dalam penelitian ini berupa video yang ditayangkan dengan bantuan LCD (Liquid Cristal Diskplay), Jadi hal-hal yang tidak dapat ditemukan siswa berkaitan dengan materi perubahan gerak, arah, maupun bentuk benda terhadap gaya yang diberikan dapat dibantu dengan virtual lab untuk menambah pengetahuan siswa.

Berbeda halnya dengan kelas kontrol, proses pembelajaran dilakukan dengan cara menyampaikan materi kepada siswa setelah itu siswa diminta untuk menemukan informasi yang berada pada buku siswa. Langkah selanjutnya dilanjutkan dengan tanya jawab kemudian diikuti dengan pemberian tugas secara individu. Dengan 
pembelajaran seperti ini, siswa tidak mempunyai kesempatan untuk mengembangkan kemampuan dan memperoleh informasi yang lebih banyak.

Hasil penelitian ini diperkuat oleh penelitian Wirati (2014) yang menyatakan bahwa model pembelajaran SETS berpengaruh terhadap hasil belajar siswa siswa kelas V SD gugus VI Kapal tahun ajaran 2013/2014.

Implikasi dalam penelitian adalah sebagai berikut. Model pembelajaran SETS berbantuan virtual lab dapat digunakan oleh guru dalam pembelajaran khususnya pembelajaran IPA, karena sudah terbukti bahwa model pembelajaran SETS berbantuan virtual lab dapat mempengaruhi kompetensi penegtahuan IPA siswa menjadi lebih baik. Dengan digunakannya model pembelajaran SETS berbantuan virtual lab dalam pembelajaran, membuat pembelajaran menjadi lebih menarik, menyenangkan, dan tidak menoton. Hal ini dikarenakan pembelajaran dengan menggunakan model pembelajaran SETS berbantuan virtual lab mengajak siswa untuk memperoleh informasi tidak hanya dari buku melainkan memanfaatkan lingkungan, masyarakat, dan teknologi, jadi pembelajaran tidak hanya dilakukan di dalam kelas yang akan membuat siswa bosan tetapi di lakukan dengan memanfaatkan lingkungan.

Selain itu pembelajaran juga memanfaatkan virtual lab berupa video yang membuat pembelajaran menjadi lebih menarik dan menyenangkan. Agar pembelajaran berlangsung lebih efektif dan mencapai tujuan pembelajaran, maka dalam menerapkan model pembelajaran SETS berbantuan virtual lab sebaiknya menggunakan kelompok kecil yang bersifat heterogen dengan terdiri dari 3 sampai 4 orang setiap kelompok. Terlalu banyak anggota kelompok dapat membuat proses pembelajaran menjadi tidak efektif, karena dapat mengurangi keaktifan dan rasa tanggungjawab masing-masing anggota kelompok.

\section{Simpulan dan Saran}

Berdasarkan hasil analisis data kompetensi pengetahuan IPA pada kelompok eksperimen, diketahui bahwa $\bar{X}$ $=75,72$ dengan perolehan nilai minimum 46 dan nilai maksimum 100. Sesuai analisis nilai kompetensi pengetahuan IPA siswa pada kelompok eksperimen, kemudian dibandingkan dengan nilai $\mathrm{M} \%=75,72$ yang kemudian dikonversikan pada tabel PAP skala lima, dapat diketahui kompetensi pengetahuan matematika siswa kelompok eksperimen berada pada kategori sedang.

Berdasarkan hasil analisis data kompetensi pengetahuan IPA pada kelompok kontrol, diketahui bahwa $\bar{X}=$ 65,66 dengan perolehan nilai minimum 36 dan nilai maksimum 96. Sesuai analisis nilai kompetensi pengetahuan matematika siswa pada kelompok kontrol, kemudian dibandingkan dengan nilai $\mathrm{M} \%=65,66$ yang kemudian dikonversikan pada tabel PAP skala lima, dapat diketahui kompetensi pengetahuan IPA siswa kelompok kontrol berada pada kategori sedang.

Berdasarkan hasil analisis data diperoleh thitung sebesar 2,96. Harga tersebut kemudian dibandingkan dengan harga $t_{\text {tabel. }}$. Harga $t_{\text {tabel }}$ diperoleh dari tabel nilai-nilai dalam distribusi $t$ dengan derajat kebebasan $(\mathrm{dk}=32+47-2=$ 77), pada taraf signifikansi 5\%. Berdasarkan tabel nilai-nilai dalam distribusi t diperoleh harga $t_{\text {tabel }}$ sebesar 1,980 . Karena $t_{\text {hitung }}>t_{\text {tabel }}(2,96>1,980)$ maka $H_{o}$ ditolak. Hal ini berarti terdapat perbedaan yang signifikan kompetensi pengetahuan IPA kelompok siswa yang dibelajarkan melalui model pembelajaran SETS (Science, Environment, Technology, Society) berbantuan Virtual Laboratory (Virtual lab) dan kelompok siswa yang dibelajarkan tidak melalui model pembelajaran SETS (Science, Environment, Technology, Society) berbantuan Virtual Laboratory (Virtual lab) pada siswa kelas IV SD Gugus Mayor Metra Denpasar Utara tahun ajaran 2016/2017. Jadi dapat disimpulkan model pembelajaran SETS (Science, Environment, Technology, Society) berbantuan Virtual Laboratory (Virtual lab) berpengaruh terhadap kompetensi IPA siswa kelas IV SD Gugus Mayor Metra Denpasar Utara tahun ajaran 2016/2017.

\section{Daftar Pustaka}

Dantes, Nyoman. 2012. Metode Penelitian. Yogyakarta: Andi.

Daryanto. 2014. Pendekatan Pembelajaran Saintifik Kurikulum 2013. Yogyakarta:Gava Media

Facthan, Ahmad. 2014. "Pengaruh Model Pembelajaran Science, Environment, Technology, Society (SETS) terhadap Kemampuan Berkomunikasi Secara Tertululis Berupa Penulisan Karya Ilmiah Bidag Geografi Siswa SMA”. e-Jurnal Pendidikan dan Pembelajaran Volume 21 No. 1 Tahun 2014. Tersedia pada http://journal.um.ac.id (diakses tanggal 3 Januari 2017)

Hermawan, Asep Herry. 2010. Pengembangan Kurikulum dan Pembalajaran. Jakarta: Universitas Terbuka.

Hermansyah. 2015. Pengaruh Laboratorium Virtual terhadap Penguasaan Konsep dan Kemampuan Berfikir Kreatif pada Materi Getaran dan Gelombang. e-Jurnal Pendidikan Fisika dan Teknologi (Volume 1 No. 2 Tahun 2015).

Suarjana, I Made dan I Made Ngurah Japa. 2015. Pendidikan Matematika III Berpendekatan PMRI dan Perubahan Konstektual. Singaraja: Universiatas Pendidikan Ganesha.

Sutarno, Nono. 2008. Materi dan Pembelajaran IPA SD. Jakarta: Universitas Terbuka.

Kosasih, E. 2014. Strategi Belajar dan Pembelajaran Implementasi Kurikulum 2013. Bandung: Yrama Widya. 
Samatowa, Usman. 2011. Pembelajaran IPA di SD. Jakarta: PT Indeks Permata Puri Media.

Wisudawati, Asih Widi dan Eka Sulistyowati. 2014. Metodelogi pembelajaran IPA. Jakarta: Bumi Aksara.

Wirati, Ayu Nyoman. 2014. "Pengaruh Model SETS (Science, Environment, Technology, and Society) Berbantuan Media Question Card terhadap Hasil Belajar IPS Kelas V SD Gugus VI Mengwi Tahun Ajaran 2013/2014”. Jurnal Mimbar PGSD Universitas Pendidikan Ganesha Volume 2 No. 1 Tahun 2014. Tersedia pada http:// ejournal.undiksha.ac.id (diakses tanggal 8 Januari 2017). 